\title{
Effect of Different Quality Irrigation Water on the Growth, Mineral Concentration and Physiological Parameters of Viburnum tinus Plants
}

\author{
M.J. Gómez-Bellot, M. Castillo, S. Álvarez, \\ J.R. Acosta, J.J. Alarcón, M.F. Ortuño and M.J. \\ Sánchez-Blanco \\ Centro de Edafología y Biología Aplicada del \\ Segura \\ CEBAS-CSIC \\ Apdo. 164, 30100-Murcia \\ Spain
}

\author{
S. Bañon \\ Departamento de Producción \\ Agraria. \\ Universidad Politécnica de \\ Cartagena (UPCT) \\ 30203- Cartagena \\ Spain
}

Keywords: stomatal conductance, photosynthesis, ornamental plants, salinity, water relations

\begin{abstract}
Treated wastewater may be considered an alternative source of water and fertilizer nutrients for landscape plants. However, $\mathrm{NaCl}$, the principal compound in this water, can be detrimental to plants. Viburnum tinus plants were submitted for 4 months to 4 irrigation treatments with water from different sources: control (Control) $\left(\mathrm{EC}<0.9 \mathrm{dS} \mathrm{m}^{-1}\right)$; $\mathrm{NaCl}$ solution $(\mathrm{NaCl})\left(\mathrm{EC}=4 \mathrm{dS} \mathrm{m}^{-1}\right)$; irrigation water normally used in the area (IW) $\left(\mathrm{EC}=1.2-1.8 \mathrm{dS} \mathrm{m}^{-1}\right)$ and reclaimed water $(\mathrm{RW})(\mathrm{EC}$ $\left.=4 \mathrm{dS} \mathrm{m}^{-1}\right)$. During a recovery period of two months, all the plants were irrigated with the control water. The results showed that biomass was affected in $\mathrm{NaCl}$, IW and RW treatments, both leaf area and height decreased at the end of saline period. These changes were more pronounced in the $\mathrm{NaCl}$ treatment, which also caused a decrease in stem diameter and root/shoot ratio. The similar growth alterations founded after the recovery period showed that salts continued to be present in the substrate. Compared with the control, $\mathrm{NaCl}$ and $\mathrm{RW}$ plants showed a greater rate of $\mathrm{Na}^{+}$and $\mathrm{Cl}^{-}$absorption by roots. Stem water potential was mainly affected by the $\mathrm{NaCl}$ treatment in the last weeks of the saline period. Through the experiment, the stomatal conductance and photosynthesis values were the lowest in plants that received the highest amount of salts, especially $\mathrm{NaCl}$ treatment which was the only treatment that did not recover at the end of experiment. Plants of the IW treatment showed slight changes in stomatal conductance and photosynthetic rate with respect to the control, although the reduction in the growth and size of these plants suggests that slight increases in EC could be very toxic for this species. Hence, using different sources of water with similar $\mathrm{EC},(\mathrm{NaCl}$ and $\mathrm{RW})$ it is important to know the exact composition, since the toxic effects produced by high concentrations of $\mathrm{Na}^{+}$and $\mathrm{Cl}^{-}$ might be offset by the effect of other ions like magnesium, potassium and phosphorus. In the physicochemical analysis of water, the highest concentrations of these ions were observed in $\mathrm{RW}$ and as consequence, their concentrations in plants were not reduced by the $\mathrm{Na}^{+}$and $\mathrm{Cl}^{-}$effect, phosphorus even increased, improving the plant nutritional balance.
\end{abstract}

\section{INTRODUCTION}

The use of non-conventional water resources, as reclaimed water, is common in many areas of the world, especially in arid and semiarid environments (Yermiyahu et al., 2008) and is becoming in an alternative to guarantee the irrigation (Elbana et al., 2010). 
Nevertheless in the ornamental plant production, the high concentration of toxic elements presents in this kind of water could cause damage in soil quality and nutrient balance inducing a decrease of quality and landscape value of these plants. Most landscape plantings include a variety of different plant species with different abilities to tolerate salt in irrigation water. So, it is important to select plants which have some mechanisms that help to tolerance the osmotic and saline damages whereas their aesthetic value is not affected.

A high concentration of salts in the root system causes a water deficit in plant due to the decrease of water potential in root medium (osmotic effect) (Alvarez et al., 2012). In addition the absorption of certain ions induces an accumulation of those in the plant tissues searching toxic levels and affecting to nutritional balance. As a consequence, salinity affects important process as photosynthesis, respiration, protein synthesis, enzymatic activities and transport of solutes (Chaves et al., 2011).

Viburnum tinus (durillo) is a perennial shrub, autochthon of Iberian Peninsula which grow throughout Mediterranean regions. It is cultivate in gardening forming hedges or as an individual plant. This specie needs few water requirements, but it has been classified as a salt-sensitive (Bañon et al., in press). The aim of this work was to study the effect of irrigation water from different sources, including reclaimed water, in the growth and quality of plant, water relations, gas exchange and photosynthetic activity of Viburnum tinus.

\section{MATERIALS AND METHODS}

\section{Plant material and experimental conditions}

Viburnum tinus plants $(\mathrm{n}=160)$ with an initial height of $20 \mathrm{~cm}$ were transplanted on $23^{\text {th }}$ March 2010 into $2.5 \mathrm{~L}$ polyethylene pots (diameter $17 \mathrm{~cm}$, height $14 \mathrm{~cm}$ ) containing a substrate of coconut fibre, black and blond peat, and perlite, (8:7:1) amended with $2 \mathrm{~g} \mathrm{~L}^{-1}$ of Osmocote Plus (14:13:13 N, P, K plus microelements). The pots were placed into a plastic greenhouse in the CEBAS experimental farm located in Santomera (Murcia, Spain), equipped with a cooling system constituted by three extractor fans with $38000 \mathrm{~m}^{3} \mathrm{~h}^{-1}$ of caudal and a humid panel. The program of cooling system guarantied his function when temperature exceed of $22^{\circ} \mathrm{C}$. The saline period began on $29^{\text {th }}$ April 2010 and during twenty weeks plants were subjected to four irrigations treatments with water different sources. The irrigation treatments consisted of a control corresponding to $100 \%$ water holding capacity, Control (EC $<0.9 \mathrm{dS} \mathrm{m}^{-1}$, leaching $15 \%$ of the applied water); $\mathrm{NaCl}$ solution, $\mathrm{NaCl}$ (EC: $4 \mathrm{dS} \mathrm{m}^{-1}$, leaching 50\%); irrigator's water, IW (EC: $1.2-1.8 \mathrm{dS}$ $\mathrm{m}^{-1}$, leaching 25\%); and reclaimed water, RW (EC: $4 \mathrm{dS} \mathrm{m}^{-1}$, leaching 50\%) which came from a sewage treatment plant located in Campotejar (Murcia, Spain). On $15^{\text {th }}$ September 2010 and during nineteen weeks, plants of $\mathrm{NaCl}$, IW and RW treatments were irrigated with water correspond to control treatment (recovery period). The assay was finished on $11^{\text {th }}$ November 2010, thirty three weeks elapsing since transplant.

\section{Water analyses}

The inorganic solute content, $\mathrm{pH}$ and $\mathrm{EC}$ of the irrigation water were assessed at the beginning of the experiment. The concentrations of macronutrients $\left(\mathrm{Na}^{+}, \mathrm{K}^{+}, \mathrm{P}^{+}, \mathrm{Ca}^{2+}\right.$ and $\left.\mathrm{Mg}^{2+}\right)$, micronutrients $\left(\mathrm{B}^{+}\right.$and $\left.\mathrm{S}^{-}\right)$were determined by inductively coupled plasma (ICP-ICAP 6500 DUO, Thermo, England); anions (chloride, nitrate, phosphate and sulphate) were analysed by ion chromatography with a Metrhom Chromatograph 
(Switzerland); $\mathrm{pH}$ was measured with a Cryson-507 PH-meter (Crisom Instruments S.A. Barcelona, Spain); electrical conductivity (EC) and total dissolved solids (TDS) were determined using the multirange equipment, Cryson-HI8734 turbidity meter (Crisom Instruments S.A. Barcelona, Spain) and turbidity was measured with a Dinko-D-110 (Dinko Instruments S.A., Barcelona, Spain).

\section{Measurements of growth and mineral content}

After saline and recovery phase plants were divided into shoots (leaves and stems) and roots and oven-dried at $80{ }^{\circ} \mathrm{C}$ until they reached a constant weight to measure the total dry biomass and to calculate root/shoot ratio. The leaf number was estimated and total leaf area (cm2) was determined using a leaf area meter (Delta-T; Devices Ltd., Cambridge, UK). Moreover, periodic measurements of height were taken during the experiment.

The inorganic solute content $\left(\mathrm{Cl}^{-}, \mathrm{Na}^{2+}\right.$ and $\left.\mathrm{B}^{+}\right)$leaves and roots were determined with dry mass at the end of saline period. The concentration of $\mathrm{Cl}^{-}$was analysed in the aqueous extracts by a chloride analyzer (Chloride Analyser Model 926, Sherwood Scientific Ltd.) and the content of $\mathrm{Cl}^{-}$and $\mathrm{B}^{+}$were determined by Inductively Coupled Plasma optical emission spectrometer (ICP-OES IRIS INTREPID II XDL). The absorption rate of $\mathrm{Na}^{+}$, $\mathrm{Cl}^{-}$and $\mathrm{B}^{+}$ions by the root system $(\mathrm{J})$ was calculated considering the total salt content expressed as mmol Na${ }^{+}, \mathrm{Cl}^{-}$and $\mathrm{B}^{+}$and the mean root weight, using the formula described by Pitman (1975): $\mathrm{J}=\left(\mathrm{M}_{2}-\mathrm{M}_{1}\right) /(\mathrm{WR} * \mathrm{t})$.

\section{Water relations}

Stem water potential $\left(\Psi_{\text {stem }}\right)$ was estimated throughout the experiment at midday, in leaves which were been covered leaves at least two hours before measurements according to Scholander et al. (1965), using a pressure chamber (Model 3000; Soil Moisture Equipment Co., Santa Barbara, CA, USA). Leaf stomatal conductance $\left(\mathrm{g}_{\mathrm{s}}\right)$ and net photosynthetic rate $\left(\mathrm{P}_{\mathrm{n}}\right)$ were measured in six plants per treatment at midday, using a gas exchange system (LI-6400; LI-COR Inc., Lincoln, NE, USA).

\section{Statistics}

In the experiment 40 plants were randomly attributed to each treatment. The data were analysed by one-way ANOVA using Statgraphics Plus for Windows. Treatment means were separated with Duncan's Multiple Range Test $(\mathrm{P} \leq 0.05)$.

\section{RESULTS}

The water from $\mathrm{RW}$ and $\mathrm{NaCl}$ treatments had similar values of $\mathrm{EC}, \mathrm{pH}$ and TDS (Table 1). The sodium and the chloride content in the water of $\mathrm{NaCl}$ treatment was more than 15 and 18-times higher, respectively, than the control treatment, causing Nephelometrical Turbidity Units (NTU) up to 4 times higher than in the control treatment. The highest boron, calcium, potassium, magnesium, phosphorus, sulphur and sulphate values were obtained in the water of RW treatment (Table 1). The IW treatment showed intermediate values between the Control and the salinity treatments for most ions. After four months of applied irrigation treatments, the total dry biomass decreased in all treatments with respect to Control, without recovering at the end of the experiment (Table 2), even $\mathrm{NaCl}$ tended to decrease with respect to other saline treatments. The leaf number in the highest saline treatments $(\mathrm{NaCl}$ and $\mathrm{RW})$ was lower than the Control, whereas the total leaf area was affected in all treatments (Table 2). Although at the end of the recovery 
period these parameters did not show significant differences respect to Control. The root/shoot ratio tended to decrease in $\mathrm{NaCl}$ and increase in IW. As regards the height, the three saline treatments remained lower than the Control during the experiment (Table 2). $\mathrm{Na}^{+}$and $\mathrm{Cl}^{-}$accumulated in the leaves of the plants subjected to the highest salinity treatments (Table 3). Curiously, the lowest values of $\mathrm{B}^{+}$were found in leaves in the RW plants, with no significant differences between the rest of treatments (Table 3 ). In plants treated with $\mathrm{NaCl}$ and $\mathrm{RW}$ a higher rate of $\mathrm{Na}^{+}$and $\mathrm{Cl}^{-}$absorption by roots was observed (Fig. 1). The lowest values in $\mathrm{B}^{+}$absorption were found for $\mathrm{NaCl}$ and $\mathrm{IW}$ whereas the rate for RW did not show significant differences with respect to the Control (Fig. 1). Midday stem water potential was mainly affected by $\mathrm{NaCl}$ treatment in the last weeks of the saline period (Fig. 2). Through the experiment, the stomatal conductance and photosynthesis values were the lowest in plants that received the highest amount of salts, especially $\mathrm{NaCl}$ treatment which was the only treatment that did not recover at the end of experiment (Fig. 3). Plants of the IW treatment showed slight changes in stomatal conductance and photosynthetic rate with respect to the control (Fig. 3).

\section{DISCUSSION}

There are few references to the effect of using reused water for irrigation on the physiological behaviour of ornamental plants (Gori et al., 2000) although is known that reclaimed water may contain high concentrations of salts, causing a reduction in growth and development, especially in non salt-tolerant species (Wu et al., 2001). In our experiment, in spite the differences found in water quality, all the treatments assayed produced a significant reduction in the biomass, total leaf area and height, even in the plants irrigated with water of EC of $1.71 \mathrm{dS} \mathrm{m}^{-1}$. In general growth did not recover at the end of experiment due to the salts present in the substrate. In this sense, Viburnum tinus, Mediterranean specie adapted to environmental conditions, was sensitive to the salts (Bañon et al., in press ). During recovery period the plants irrigated with $\mathrm{NaCl}$ and $\mathrm{RW}$ treatments had new leaves increasing the total leaf area until to reaching no significant differences with the Control plants. In these plants $(\mathrm{NaCl}$ and $\mathrm{RW})$ a higher $\mathrm{Na}^{+}$and $\mathrm{Cl}^{-}$ absorption rate were produced, especially for the $\mathrm{Na}^{+}$, whereas $\mathrm{Cl}^{-}$was accumulated similarly in the leaves and roots, which produced symptoms such as chlorosis and senescence. The high absortion of $\mathrm{B}^{+}$ion by root in plants irrigated with $\mathrm{RW}$ did not have negative effects on plants due to this element (Wu and Dodge, 2006). Nevertheless, although similar morphological responses in plants were observed in $\mathrm{RW}$ and $\mathrm{NaCl}$, the latter caused more effect in the photosynthetic system, reaching the lowest values of gs and $\mathrm{Pn}$. Maybe the higher contents of magnesium, sulphur, $\mathrm{Ca}^{2+}, \mathrm{K}^{+}$and $\mathrm{P}^{+}$in $\mathrm{RW}$ could improve the nutrition with respect to plants irrigated with $\mathrm{NaCl}$ (Gori et al., 2000), making a quickly recovery of physiological parameters. The osmotic effect provoked in the plant water status by the salinity was similar in all treatments, as we can see from the

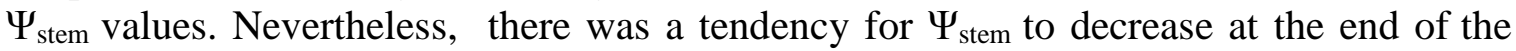
saline period as a consequence of dehydratation throughout the experiment due to difficulty in taking up water from the substrate (Álvarez et al., 2012). This behaviour also occurred for gs and Pn values, the reduction in Pn was related with a stomatal limitation (Bacelar et al., 2007), although this observation does not exclude the possibility of metabolic damage due to salinity, especially in $\mathrm{NaCl}$ and $\mathrm{RW}$ at the end of the saline period. Which, could be related to the high concentration of $\mathrm{Cl}^{-}$and $\mathrm{Na}^{+}$in their leaves (Álvarez et al., 2012). 


\section{ACKNOWLEDGEMENTS}

This work was supported by the projects: CICYT (AGL 2008- 05258-CO2-1-2AGR and AGL 2011-30022-CO2-01-02), Fundación Séneca (15356/PI/10) and Vías y Construcción, S. A. (CDTI IDI-20101191).

\section{Literature Cited}

Álvarez, S., Gómez-Bellot, M.J., Castillo, M., Bañón, S. and Sánchez- Blanco, M.J. 2012. Osmotic and saline effect on growth, water relations, and ion uptake and translocation in Phlomis purpurea plants. Environ. Exp. Bot. 78:138-45.

Bacelar, E.A., Moutinho-Pereira, J.M., Gonçalves, B.C., Ferreira, H.F. and Correia, C.M. 2007. Changes in growth, gas exchange, xylem hydraulic properties and water use efficiency of three olive cultivars under contrasting water availability regimes. Environ. Exp. Bot. 60:183-192.

Bañón, S., Miralles, J., Ochoa, J. and Sánchez-Blanco, M.J. 2012. The effect of salinity and high boron on growth, photosynthetic activity and mineral contents of two ornamental shrubs. HortSci. (in press)

Chaves, M.M., Miguel, C.J. and Madeira, S.N.J. 2011. Chapter 3 Recent advances in photosynthesis under drought and salinity. In: Tukan, I. (Ed), Advances in botanical research. Academic Press 57: 49-104.

Elbana, M., Puig-Bargues, J., Pujol, J. and de Cartagena, F.R. 2010. Preliminary planning for reclaimed water reuse for agricultural irrigation in the province of Girona, Catalonia (Spain). Desalin. Water Treat. 22:47-55.

Gori, R., Ferrini, F., Nicese, F.P. and Lubello, C. 2000. Effect of reclaimed wastewater on the growth and nutrient content of three landscape shrubs. J. Environ. Hort. 18:10814.

Pitman, M.G. 1975. Ion trasnport in whole plants. In: Baker DA, Hall JL, editors. Ion transport in plant cells and tissues. Amsterdam: North-Holland Publishing Co. p 267308.

Scholander, P.F., Hammel, H.T., Bradstreet, E.D., Hemingsen, E.A. 1965. Sap pressure in vascular plants. Science 148: 339- 346.

$\mathrm{Wu}, \mathrm{L}$. and Dodge, L. 2005. Landscape plant salt tolerance selection guide for recycled water irrigation. In: J Slosson Endowment Fund. A Special Report for the Elvenia. University of California, Davis. p 40.

Wu, L., Skaggs, T.H., Shouse, P.J. and Ayars, J.E. 2001. State space analysis of soil water and salinity regimes in a loam soil underlain by shallow groundwater. Soil Sci. Soc. Am. J. 65:1065-1074.

Yermiyahu, U., Ben-Gal, A., Keren, R., Reid , R.J. 2008. Combined effect of salinity and excess boron on plant growth and yield. Plant Soil 304:73-87. 


\section{$\underline{\text { Tables }}$}

Table 1. Physicochemical analyses from the different irrigations treatments. Data are values from samples collected at the beginning of saline period.

\begin{tabular}{|c|c|c|c|c|}
\hline \multirow{2}{*}{$\begin{array}{c}\text { Physicochemical } \\
\text { Analyses }\end{array}$} & \multicolumn{4}{|c|}{ Treatments } \\
\hline & Control & $\mathrm{NaCl}$ & IW & RW \\
\hline pH & 7.97 & 7.78 & 8.17 & 7.67 \\
\hline $\mathrm{EC}\left(\mathrm{dS} \mathrm{m}^{-1}\right)$ & 0.87 & 4.24 & 1.71 & 4.19 \\
\hline TDS (mg/L) & 383 & 1626 & 720 & 1785 \\
\hline Turbidity (NTU) & 2.10 & 8.16 & 2.88 & 3.2 \\
\hline B (mg/L) & 0.09 & 0.06 & 0.20 & 1.08 \\
\hline $\mathrm{Ca}(\mathrm{mg} / \mathrm{L})$ & 94.21 & 82.54 & 92.45 & 186.35 \\
\hline K $(\mathrm{mg} / \mathrm{L})$ & 3.39 & 4.17 & 10.51 & 48.27 \\
\hline$M g(m g / L)$ & 41.87 & 37.79 & 54.14 & 148.80 \\
\hline $\mathrm{Na}(\mathrm{mg} / \mathrm{L})$ & 52.07 & 801.3 & 187.90 & 662.30 \\
\hline$P(\mathrm{mg} / \mathrm{L})$ & 0.22 & $<0.1$ & 0.7 & 1.62 \\
\hline$S(\mathrm{mg} / \mathrm{L})$ & 85.6 & 64.81 & 112.90 & 310.30 \\
\hline Chlorides (mg/L) & 69.50 & 1295.90 & 600.70 & 816.80 \\
\hline Nitrates (mg/L) & $<0.1$ & 1.37 & 4.25 & 0.58 \\
\hline Sulphates $(\mathrm{mg} / \mathrm{L})$ & 220.12 & 157.87 & 750.20 & 1044.03 \\
\hline
\end{tabular}

Table 2. Growth and development parameters in Viburnum tinus plants irrigated with water from different sources and quality at the end of saline (S) and recovery (R) period. Values are mean of five plants.

\begin{tabular}{|c|c|c|c|c|c|c|c|c|c|c|c|c|c|c|c|c|c|}
\hline \multirow{2}{*}{\multicolumn{2}{|c|}{$\begin{array}{c}\text { Measured } \\
\text { parameters }\end{array}$}} & \multicolumn{15}{|c|}{ Treatments } & \multirow{2}{*}{$\mathbf{P}$} \\
\hline & & \multicolumn{4}{|c|}{ Control } & \multicolumn{4}{|c|}{$\mathrm{NaCl}$} & \multicolumn{4}{|c|}{ IW } & \multicolumn{3}{|c|}{ RW } & \\
\hline \multirow{2}{*}{$\begin{array}{c}\text { Biomass } \\
\text { DW } \\
\left(\text { g plant }^{-1}\right)\end{array}$} & $\mathbf{S}$ & 60.86 & \pm & 5.32 & $\mathrm{~b}$ & 38.85 & \pm & 1.83 & $\mathrm{a}$ & 44.77 & \pm & 1.96 & $\mathrm{a}$ & 38.40 & $\pm 4.20 \mathrm{~A}$ & $\mathrm{a}$ & $* *$ \\
\hline & $\mathbf{R}$ & 83.56 & \pm & 7.55 & $\mathrm{c}$ & 43.52 & \pm & 5.12 & $a b$ & 51.70 & \pm & 5.17 & $\mathrm{~b}$ & 54.14 & $\pm 7.62 \mathrm{~A}$ & $\mathrm{~b}$ & $* * *$ \\
\hline \multirow{2}{*}{$\begin{array}{c}\text { Leaf } \\
\text { number }\end{array}$} & $\mathbf{S}$ & 403.50 & \pm & 31.14 & bA & 285.50 & \pm & 29.11 & $\mathrm{a}$ & 334.20 & \pm & 20.61 & $a b$ & 293.30 & \pm 35.58 & $\mathrm{a}$ & $*$ \\
\hline & $\mathbf{R}$ & 501.12 & \pm & 41.27 & A & 303.91 & \pm & 35.20 & & 360.63 & \pm & 41.46 & & 334.29 & \pm 32.13 & & ns \\
\hline \multirow{2}{*}{$\begin{array}{l}\text { Total leaf } \\
\text { area }\left(\mathbf{d m}^{2}\right)\end{array}$} & $\mathbf{S}$ & 25.87 & \pm & 4.41 & $\mathrm{~b}$ & 14.35 & \pm & 0.68 & $\mathrm{a}$ & 16.96 & \pm & 0.81 & $\mathrm{a}$ & 14.59 & \pm 1.48 & $\mathrm{a}$ & $*$ \\
\hline & $\mathbf{R}$ & 26.60 & \pm & 3.02 & & 17.12 & \pm & 2.52 & & 18.00 & \pm & 2.76 & & 20.69 & \pm 4.11 & & ns \\
\hline \multirow{2}{*}{$\begin{array}{l}\text { Root/Shoot } \\
\text { ratio }\end{array}$} & $\mathbf{S}$ & 0.43 & \pm & 0.04 & $\mathrm{ab}$ & 0.36 & \pm & 0.03 & $\mathrm{a}$ & 0.50 & \pm & 0.03 & $\mathrm{~b}$ & 0.40 & \pm 0.02 & $\mathrm{ab}$ & $*$ \\
\hline & $\mathbf{R}$ & 0.52 & \pm & 0.07 & $\mathrm{~b}$ & 0.38 & \pm & 0.07 & $\mathrm{ab}$ & 0.30 & \pm & 0.02 & $\mathrm{a}$ & 0.49 & $\pm \quad 0.03$ & $\mathrm{~b}$ & $*$ \\
\hline \multirow{2}{*}{ Height } & $\mathbf{S}$ & 60.74 & \pm & 3.80 & $\mathrm{~b}$ & 48.83 & \pm & 2.83 & $\mathrm{a}$ & 46.22 & \pm & 1.50 & $\mathrm{a}$ & 50.68 & \pm 2.25 & $\mathrm{a}$ & $* * *$ \\
\hline & $\mathbf{R}$ & 64.47 & \pm & 3.66 & $\mathrm{~b}$ & 51.44 & \pm & 2.66 & $\mathrm{a}$ & 53.22 & \pm & 1.44 & $\mathrm{a}$ & 51.42 & \pm 2.21 & $\mathrm{a}$ & $* * *$ \\
\hline
\end{tabular}

Means within a row without a common lowercase letter are significantly different by

Duncan $_{0.05}$ test. Means within a column without a common capital letter are significantly different by Duncan $_{0.05}$ test.

$\mathrm{P}$, probability level; ns, not significant; $* \mathrm{P} \leq 0.05 ; * * \mathrm{P} \leq 0.01 ; * * * \mathrm{P} \leq 0.001$. 
Table 3. $\mathrm{Na}^{+}, \mathrm{Cl}^{-}$and $\mathrm{B}^{+}$concentration in leaf and root in Viburnum tinus plants irrigated with water from different sources and quality at the end of saline period. Values are mean of five plants.

\begin{tabular}{|c|c|c|c|c|c|c|c|c|c|c|c|c|c|c|c|c|}
\hline \multirow{2}{*}{\multicolumn{2}{|c|}{$\begin{array}{c}\text { Solutes } \\
\left(\mathrm{mg} \mathrm{k}^{-1} \mathrm{DW}\right)\end{array}$}} & \multicolumn{14}{|c|}{ Treatments } & \multirow{2}{*}{$\mathbf{P}$} \\
\hline & & \multicolumn{4}{|c|}{ Control } & \multicolumn{3}{|c|}{$\mathrm{NaCl}$} & \multicolumn{4}{|c|}{ IW } & \multicolumn{3}{|c|}{ RW } & \\
\hline \multirow{2}{*}{${ }^{+\pi}$} & Leaf & 365 & \pm & 103 & $\mathrm{a}$ & 7881 & \pm 1923 & b & 1329 & \pm & 287 & a & 11104 & \pm 1067 & $\mathrm{~b}$ & $* * *$ \\
\hline & Root & 2440 & \pm & 615 & $\mathrm{a}$ & 3360 & \pm 479 & $a b$ & 3713 & \pm & 396 & $a b$ & 4946 & \pm 650 & $\mathrm{~b}$ & $*$ \\
\hline \multirow{2}{*}{$\dot{U}$} & Leaf & 8240 & \pm & 2077 & $\mathrm{a}$ & 20720 & \pm 2072 & $\mathrm{~b}$ & 10400 & \pm & 938 & $\mathfrak{a}$ & 16320 & \pm 3278 & $\mathrm{~b}$ & $* * *$ \\
\hline & Root & 6800 & \pm & 1403 & $\mathrm{a}$ & 10320 & \pm 720 & $\mathrm{~b}$ & 9120 & \pm & 1007 & $\mathrm{a}$ & 10480 & \pm 889 & $\mathrm{~b}$ & $* * *$ \\
\hline \multirow{2}{*}{$\stackrel{+}{\infty}$} & Leaf & 179.43 & \pm & 2.68 & $\mathrm{~b}$ & 200.50 & \pm 7.17 & $\mathrm{~b}$ & 177.16 & \pm & 11.42 & $\mathrm{~b}$ & 147.07 & \pm 8.76 & $\mathrm{a}$ & $* *$ \\
\hline & Root & 120.69 & \pm & 2.96 & & 132.45 & \pm 9.03 & & 127.28 & \pm & 4.71 & & 118.26 & \pm 1.38 & & $\mathrm{~ns}$ \\
\hline
\end{tabular}

\section{Figures}
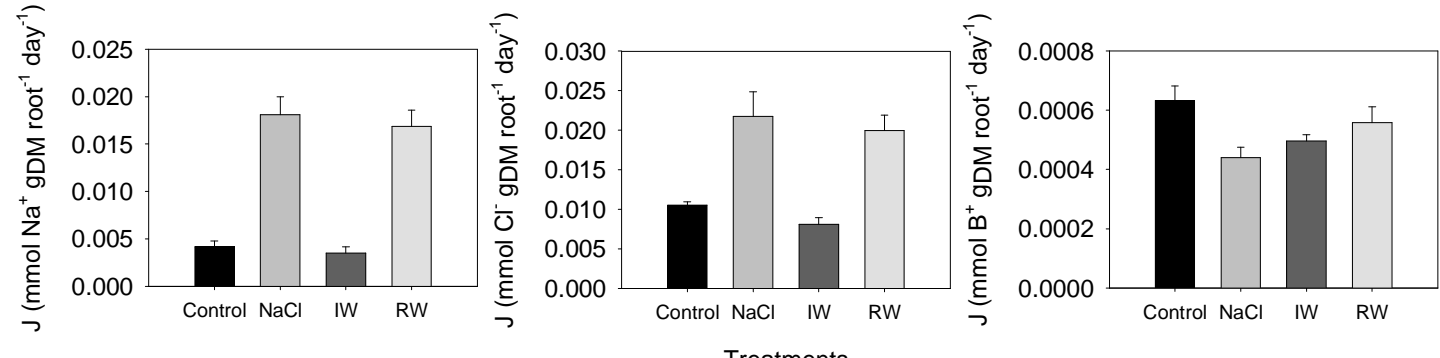

Fig.1. Absorption rate of $\mathrm{Na}^{+}(\mathrm{A}), \mathrm{Cl}^{-}(\mathrm{B})$ and $\mathrm{B}^{+}(\mathrm{C})$ ions by roots in Viburnum tinus plants irrigated with water from different sources and quality at the end of saline period. Values are mean of five plants. 


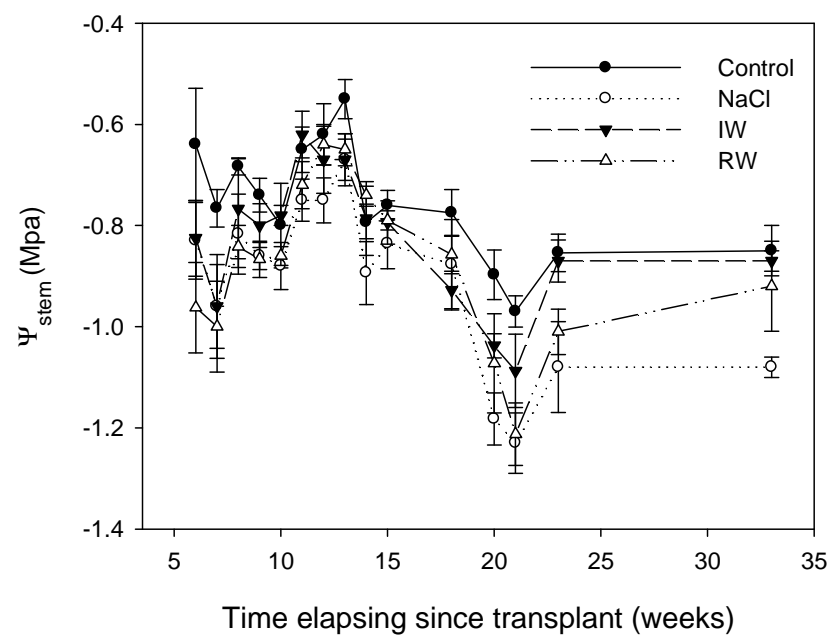

Fig.2. Evolution of stem water potential at midday in Viburnum tinus plants irrigated with water from different sources and quality at the end of saline period. Values are means of six plants per treatment.

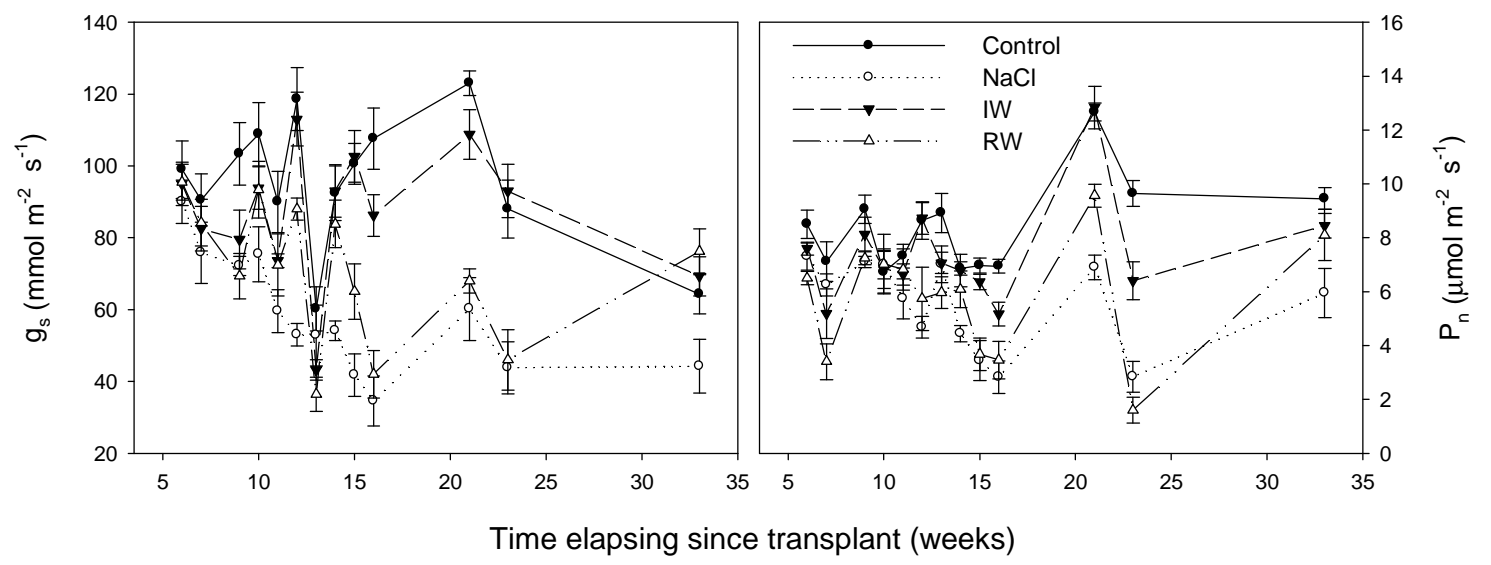

Fig.3. Evolution of stomatal conductance (A) and net photosynthetic rate (B) at midday in Viburnum tinus plants irrigated with water from different sources and quality at the end of saline period. Values are means of six plants per treatment. 